\title{
The brain in Spain
}

\author{
The legacy of Santiago Ramón y Cajal, \\ the brilliant Spanish neuroscientist, is to \\ be preserved in a new museum. But the
} fight to recover his lost works goes on, say Xavier Bosch and Alison Abbott.

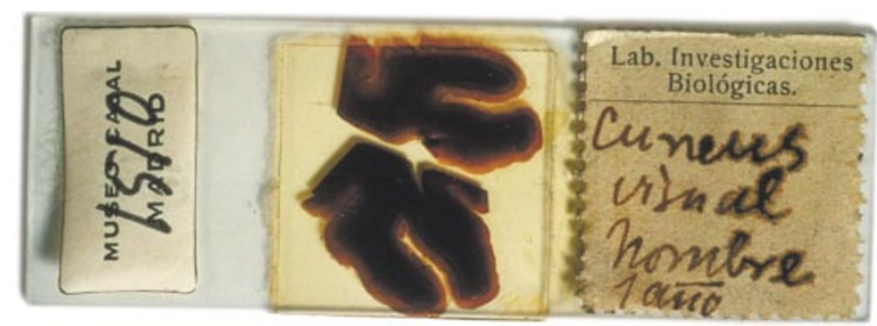

F or a boy who dreamed of being an artist, but started his career apprenticed to first a barber and then a cobbler, Santiago Ramón y Cajal made a distinguished mark in science. He was both Spain's first Nobel laureate and a founding father of modern neuroscience. But since Cajal's death in 1934, his work - including a priceless archive of drawings - has been consigned to basements, maltreated and given away as gifts.

Now Cajal's legacy is to get a permanent home in Madrid. Spain's national research agency, the CSIC, and the philanthropic Marcelino Botín Foundation agreed last month to co-sponsor the building of a Ptas130 million (US\$740,000) museum to house Cajal's collected works. It should open in 2002, the 150th anniversary of Cajal's birth.

Cajal shared the Nobel Prize in Physiology or Medicine in 1906 for his theory that the nervous system was made up of individual cells, later termed neurons. Until Cajal, most researchers supported the 'reticular' theory, believing that the system was a network in which cells fused to give long, continuous nerve fibres. As talented a draughtsman as he was a scientist, Cajal depicted the synapses that separate individual neurons in meticulous drawings of histological preparations. These rival today's images from electron and confocal microscopy.

Even more remarkable was Cajal's uncanny ability to infer function from observation. "We are still working on the theories that Cajal developed," says Marina Bentivoglio of the University of Verona. "He had tremendous insight and could understand what he saw much better than anyone, even today." Barry Everitt of the University of Cambridge, editor of the European Journal of Neuroscience, agrees: "He has rarely been shown to be wrong in his predictions about neuronal connections."

Cajal's will - handwritten one month before his death - stated that his works should be preserved at his institute in Madrid. Shortly afterwards, the collection was taken from his home to the Cajal Institute. But they were not well curated. At the end of the Spanish Civil War in 1939, they were found among rubble in the institute's basement. And although a small museum displayed a sample of Cajal's works from 1945 to 1985 , the majority remained stored in boxes.

The first general inventory took place in 1975, when Cajal's works were found scattered around offices at the institute and Madrid's Complutense University. Time and poor storage conditions had taken their toll. "The most serious damage was caused by scientists sticking adhesive tape onto original documents, writing on them or folding them," says Miguel Freire, a neuroanatomist at the Cajal Institute. But it was not until 1997, when Ricardo Martínez Murillo became director of the institute, that a concerted effort to preserve Cajal's legacy began.

Martínez Murillo appointed Freire to head the Cajal Legacy Team. The team is now making a detailed computerized inventory of Cajal's works and organizing restoration. The collection is thought to comprise about 2,000 scientific drawings, 2,300 histological preparations and 2,100 scientific and personal letters, as well as portraits, photographs, notebooks, laboratory materials and personal objects. If the collection can be turned into an accessible scientific resource, says Everitt, it would be very valuable. But about a quarter of Cajal's works are thought to have been lost.

In the past, says Cajal's grandson, Santiago Ramón y Cajal Junquera, a neuropathologist at Zaragoza University, it was common for scientific visitors to the Cajal Institute to be given a Cajal drawing as a gift. Now that the museum is in prospect, Freire and Martínez Murillo hope that those who hold Cajal artefacts will return them to the collection - they plan to issue an appeal over the Internet once the inventory is complete.

Carlos Belmonte, director of the neurosciences institute at Miguel Hernández University in Alicante, and his colleague Roberto Gallego both have Cajal drawings, given to them by Gallego's father, a pupil of Cajal's. Both say that they are prepared to discuss loaning the drawings to the new museum.

Members of Cajal's family back the appeal to return artefacts to the museum, although they are in dispute with the Cajal Institute over who actually owns them. These ques-

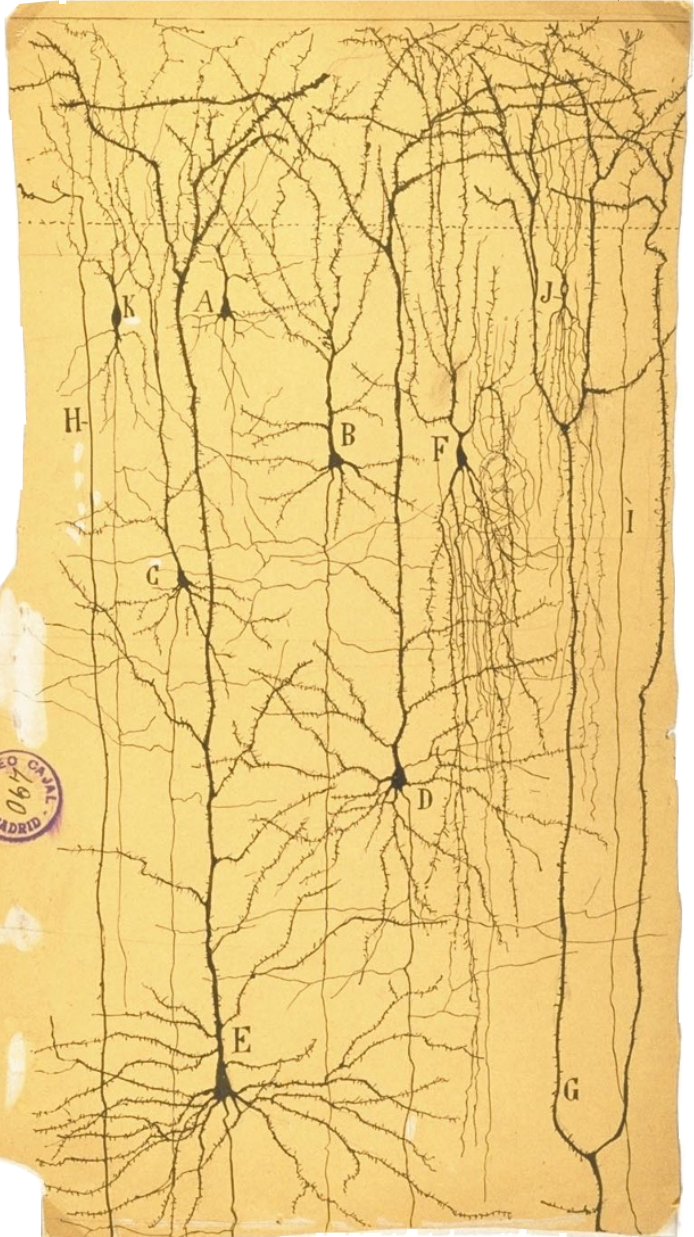

Networking: Cajal translated histological preparations (top) into intricate drawings.

tions might have been resolved two years ago, when Fernando de Castro, an heir of one of Cajal's pupils, attempted to auction his collection, and the family claimed ownership of the works. A judge blocked the sale, but did not rule on whether the artefacts belonged to the family or the institute.

The poor cataloguing and curation of the collection in Madrid may have deterred some people from returning their Cajal artefacts. The museum's supporters hope that the latest developments change their minds. "I urge all to participate in this process," says Charles Ribak, a neuroanatomist at the University of California, Irvine, and president of the Cajal Club - the oldest neuroscience organization in the United States.

Xavier Bosch writes for Nature from Barcelona; Alison Abbott is Nature's senior European correspondent. http://www.cajal.csic.es/legadoca/legadoin.htm 